\title{
Between emergency, submersion, and silence: LGBT as a research category in Administration
}

\author{
MaUrício DonaVAn Rodrigues PANIZA ${ }^{1}$ \\ ${ }^{1}$ Fundação Getulio Vargas (FGV EAESP) / Escola de Administração de EMPreSAS de SÃo Paulo, SÃo PAULO - SP, BRAZIL
}

\begin{abstract}
This article discusses the adoption of the abbreviation LGBT (lesbian, gay, bisexual, transvestite, and transsexual), questioning the representativeness of the groups contained in this acronym in Administration research. Some authors in Brazil state that, although there is the intention to construct a field of research on the subject, the agenda is mostly aimed at research on gay people (CARRIERI, SOUZA and AGUIAR, 2014). Therefore, the research question is: Is it possible to treat identity categories that are so different under the same prism? The article is grounded on (1) a historical version of the constitution of LGBT groups, showing how they are organized and fragmented in Brazil (FACCHINI, 2005); (2) a discussion on the adoption of the LGBT acronym as a universal category, based on the debate about contingent identities (BUTLER, 1998); (3) a literature review of Brazilian Administration using the SPELL database. A total of 34 articles approaching LGBT groups were found. Research on gays predominates while groups of lesbians, transvestites, and transsexuals are underrepresented. It is perceived that, although there are similarities from the point of view that all the identity categories are targets of discrimination and violence (which is justified because they are categories considered deviant), the articles mark the differences between them. It is in these differences that there are possibilities for Administration research to question the adoption of acronyms, such as LGBT, as a universally representative and unified concept.
\end{abstract}

Keywords: LGBT. Diversity. Inclusion. Sexuality. Gender identity.

\section{Entre a emergência, a submersão e o silêncio: LGBT como categoria de pesquisa em Administração}

\section{Resumo}

Este artigo discute a adoção da sigla LGBT (lésbicas, gays, bissexuais, travestis e transexuais), questionando a representatividade dos grupos que fazem parte desse acrônimo nas pesquisas em Administração. No Brasil, afirma-se que, embora se almeje construir um campo de pesquisas no assunto, sua agenda é majoritariamente destinada às pesquisas sobre gays (CARRIERI, SOUZA e AGUIAR, 2014). De modo mais específico, o questionamento é: será que é possível tratar sob o mesmo prisma categorias identitárias tão distintas? A construção do trabalho está embasada em: 1) uma versão histórica sobre a constituição dos grupos LGBT, principalmente no Brasil, evidenciando de que modo eles se organizaram e se fragmentaram (FACCHINI, 2005); 2) uma discussão sobre a adoção da sigla LGBT como categoria universal, embasada no debate sobre identidades contingentes (BUTLER, 1998); e 3) um levantamento de literatura nacional sobre grupos LGBT em Administração na base de dados Scientific Periodicals Electronic Library (SPELL). Foram encontrados 34 artigos sobre os grupos incluídos na sigla LGBT. Pesquisas sobre gays predominam enquanto grupos de lésbicas, travestis e transexuais estão sub-representados. Percebe-se que, embora haja similaridades do ponto de vista de que todas essas categorias identitárias são alvos de discriminação e violência - o que se justifica por se tratarem de categorias tidas como desviantes, as pesquisas levantadas demarcam as diferenças entre elas. É nessas diferenças que se encontram as possibilidades de a pesquisa em Administração questionar a adoção de siglas (como a LGBT) como conceitos universalmente representativos e unificados.

Palavras-chave: LGBT. Diversidade. Inclusão. Sexualidade. Identidade de gênero.

\section{Entre la emergencia, la inmersión y el silencio: LGBT como categoría de estudio en Administración}

\section{Resumen}

Este trabajo discute la adopción de la sigla LGBT (lesbianas, gays, bisexuales, travestis y transexuales) cuestionando la representatividad de los grupos contenidos en ese acrónimo en las investigaciones en Administración. En Brasil, aunque se pretenda construir un campo de investigación en el asunto, su agenda es mayoritariamente destinada a los estudios sobre gays (CARRIERI, SOUZA e AGUIAR, 2014). De forma más específica, el cuestionamiento es: ¿será posible tratar bajo el mismo prisma categorías identitarias tan distintas? La construcción del trabajo se basa en: (1) una versión histórica de la constitución de los grupos LGBT mostrando cómo se han organizado y fragmentado en Brasil (FACCHINI, 2005); (2) una discusión sobre la adopción de la sigla LGBT como categoría universal basada en el debate sobre identidades contingentes (BUTLER, 1998); (3) un levantamiento de literatura nacional sobre grupos LGBT en Administración en la base de datos Scientific Periodicals Electronic Library (SPELL). Se han encontrado 34 artículos sobre los grupos incluidos en la sigla LGBT. Los estudios sobre gays predominan mientras que grupos de lesbianas, travestis y transexuales están subrepresentados. Se percibe que, aunque haya similitudes desde el punto de vista de que todas estas categorías identitarias son blancos de discriminación y violencia, lo que se justifica por tratarse de categorías tenidas como desviantes, los estudios planteados demarcan las diferencias entre ellas. Es en esas diferencias que yacen las posibilidades de que del estudio en Administración cuestione la adopción de siglas (como LGBT) como concepto universalmente representativo y unificado.

Palabras clave: LGBT. Diversidad. Inclusión. Sexualidad. Identidad de género. 


\section{INTRODUCTION}

This article aims to understand the implications of adopting the LGBT (lesbian, gay, bisexual, transvestite, and transsexual) category in the research published in Brazilian administration journals, considering the representativeness of these social groups. The interest in addressing this issue is based on the perception that it is necessary to unveil the operating logic when it comes to the appropriation and agglutination of such distinct social groups. More specifically, the research question seeks to understand whether it is possible to use the same point of views when dealing with categories that are so different (FREITAS, 2015; NG and RUMENS, 2017), and it is important to apply critical analysis to this matter.

The term 'critical analysis' used in this study is more than a critical nature connected to a specific theoretical tradition, such as the critical theory or the dialectical and historical materialism. It means that the analysis adopts "a broad set of theoretical approaches that may help to understand the oppressive character of administration and that suggests different paths" (ALCADIPANI, 2005, p. 221). Fournier and Grey (2000, p. 16) also support this view by stating that "there is no single way of demarcating the critical [position] from the non-critical." The critical position is to debate the possibilities, understanding the differences that are not clear - in terms of language - when the LGBT category is used as an initialism of something that is homogeneous

The first theoretical inspiration to problematize LGBT as a research category was Scott (1986, p. 1053), whose work leads to the understanding that there is a 'social grammar' built historically around this initialism. The author's theoretical proposal is adopted to understand some symbolic aspects behind the initialism LGBT, the normative issues that are imposed regarding its complete comprehension, or what is interesting for the administration to understand. Also, the theoretical proposal is adopted to elucidate how this comprehension is related to the organizational field since issues of sexual and gender identities also reproduce and confront each other in this environment.

Understanding the initialism LGBT as 'homogeneous' seems to assume that it comprises groups of stable subjects who experience the world in the same way. However, according to Butler $(1998$, p. 13), "to claim that politics requires a stable subject is to claim that there can be no political opposition to that claim." In the Brazilian studies, although there is the desire to build a research field related to LGBT groups, the agenda is mainly inclined to the research about gays (CARRIERI, SOUZA and AGUIAR, 2014). When considering all the public reflected in the initialism, Carrieri, Souza and Aguiar (2014, p. 80) emphasize that LGBT "is not a homogeneous group," an aspect also stressed by Freitas (2015) and other international authors (NG and RUMENS, 2017). This observation raises the question: Does it make sense to unify the category 'LGBT' in a totalizing way of thinking, considering these groups as homogeneous?

Rethinking LGBT in studies in administration implies challenging three aspects, based on Fournier and Grey (2000) regarding the critical field. First, how much is LGBT limited to be performative because it refers to 'equality' and 'inclusion', but only includes what is already included (the gays and lesbians framed in the normative pattern of what is male and female). Second, how much does one need to denature the stable images of what it is to be $L, G, B$ or $T$, in the world of work, considering that the field of administration knows little about what is beyond L and G, and especially the groups outside 'LGBT.' Finally, the reflection on what is at stake when the initialism LGBT is used as a neutral category, disregarding the power relations that permeate its constitution. This study uses Judith Butler's concept of the contingency of identities to discuss an examination of the Brazilian literature in administration regarding the identity groups portrayed in the initialism LGBT.

The examination covered Brazilian administration journals and was conducted in the Scientific Periodicals Electronic Library (SPELL) database, using the term 'LGBT,' and the terms (including their plural form, in Portuguese) 'lésbica(s)', 'gay(s)', 'bisexual(ais)', homossexual(ais), 'travesti(s)', 'transexual(ais)', and 'transgênero(s)' [lesbian, gay, bisexual, homosexual, transvestite, transsexual, and transgender]. Because of the plurality of the terms and the use of a digital search engine some articles may not have been identified, but the study was able to collect the vast majority of the research published in administration according to the search criteria.

This article is organized in six sections including this introduction. The next section presents the methodology, followed by a third section that presents the history of the gay movement to the LGBT groups. The fourth section discusses the contingencies of LGBT as a unifying category, followed by the data obtained about the literature published in administration addressing the issue, including the research topics and the representativeness of the identity groups reflected in the initialism. Finally, the article presents a discussion of the findings and final considerations. 


\section{METHODOLOGY}

This study produced an examination of the Brazilian literature in Administration addressing the groups represented by the initialism LGBT. The theoretical framework is based on the historical review of the initialism, presenting issues related to the groups represented and the Brazilian context. Also, the study discusses the consequences of understanding LGBT as a category that reflects a supposedly universal and homogeneous identity group.

As an empirical reference, the focus of the analysis was the research published in scientific journals in administration. Although the discussions and debates on issues of sexuality and gender have also occurred in the main events of the field, the decision to analyze only the articles published was made because, according to the definition of the National Association of PostGraduation and Research in Administration (Anpad) ${ }^{1}$, the works presented at events are considered working papers, that is, they are drafts not yet prepared for publication. Also, according to Anpad, the publication in a journal is a later stage of the movement of scientific dissemination, which begins after the appreciation and debate of the work in the event.

Since sexuality and gender studies from the LGBT perspective are a recent topic in Administration, the historical cut was established between the years 2006 - when the first works on gays were published in administration journals (PEREIRA, AYROSA and OJIMA, 2006) - and 2017 - when the last work on the topic was identified (about transsexual persons) (BAGGIO, 2017), and gays (SANTOS, SILVA and CASSANDRE, 2017).

The articles were searched and mapped in the SPELL database (which brings together the Brazilian scientific production in the areas of Administration, Accounting, and Tourism). The study considered only the journals in the area of Administration. As mentioned before, the searched keywords were the term 'LGBT,' and the terms (including their plural form, in Portuguese) 'lésbica(s)', 'gay(s)', 'bisexual(ais)', homossexual(ais), 'travesti(s)', 'transexual(ais)', and 'transgênero(s)' [lesbian, gay, bisexual, homosexual, transvestite, transsexual, and transgender]. The search was carried out in the fields 'document title' and 'abstract.'

The research found 34 articles. Two of them analyzed LGBT people in general, 26 were about gays, five about lesbians, and four about transvestites and transsexuals (some research addressed more than one identity category). There were no articles on bisexual people published in administration journals in the period between 2006 and 2017. The central issues approached by each article were read and organized, allowing to interpret and synthesize the diversity of thematic axes and meanings expressed in the scientific production on the LGBT groups published in administration journals. Complementary documents were used to present the data collected when needed. However, the findings of this study are discussed based on the publications on LGBT in Brazilian administration journals researched.

\section{BUILDING A HISTORIC SENSE TO THE INITIALISM LGBT}

The history of the LGBT movement is the history of appropriation and collective dispute of meaning [...] The retrospective view shows that this history has brought positive effects to the life of the benefited subjects and that, despite all the conflicts and wear and tear in the everyday political process, important debates have been fought even within the movement. In this history, the then known as 'homosexuals' as a community separated and oppressed by a society often described as 'heterosexual,' became recognized as a complex set of political subjects who seek to address this plurality and to affirm themselves as subjects of rights (FACCHINI, 2012, p. 151).

The constitution of what was to be called LGBT groups from the 2000s has a history in Brazil that began in the 1970s, when the gay movement was organized (FACCHINI, 2012). This study focuses on the Brazilian context because the works that address the history of the lesbian, gay, transvestite and transsexual movements in an international context portray specific cultural, historical, and social scenarios not always applicable to Brazil. The narratives of these international studies about what the movements are, how they were built, and what the different LGBT identities mean, are attached to the fragmentary and contingent nature of the subjects and historical and social positions (JENNINGS, 2004).

\footnotetext{
${ }^{1}$ The difference between working papers (presented in events) and articles published in journals was stated by ANPAD during the call for papers for the XLII ANPAD Meeting (EnANPAD, 2018).
} 
The Brazilian gay movement was organized as a way to resist the repression of the military dictatorship, operating as a kind of counterculture movement. Thus, from a historical point of view, as argued by Facchini and França (2009), the term 'homosexuality' as a category (recent in Western society), was linked to the corpus of medical sciences, which designated 'homosexual' sexuality as a disease (MOTT, 2006). The first organized gay movement was constituted in 1978, named "Somos" [we are]. From the political and ideological point of view, the group presented leftist thinking, inspired by feminist and black movements that were gaining strength at the time. The group was initially formed by gay men. In 1981, lesbians started to attend the meetings, and soon there was the spinoff of another group, the Lésbico-Feminista (LF) [lesbian-feminist] (FACCHINI and FRANÇA, 2009).

As for the location, these first groups were established and operated in the states of Rio de Janeiro and São Paulo. During the 1980s there was a change in this dynamic and groups were formed and operated in the region between the state of Rio de Janeiro and the northeast of Brazil. Among the groups in the Northeast, stands out the Grupo Gay da Bahia (GGB) established under the leadership of Luiz Mott. The group's tactics shifted from the initial scope of pursuing social transformation to a more "pragmatic activity with the objective of guaranteeing civil rights and against discrimination and violence toward gay people" (FACCHINI and FRANÇA, 2009, p. 60). Also, in the 1980s, the authors evidence that there was a displacement of resistance offered by gay groups, because when adopting more pragmatic social interventions and there is more interaction with movements in an international context, movements need organized environments to operate, with items such as office, phone, organization charts. Therefore, the authors argue that, at that moment, the groups were no longer resistant to the institutions as they were previously, during the period of the military dictatorship (FACCHINI and FRANÇA, 2009).

However, the gays and lesbian movements were threatened in the mid-1980s by acquired immunodeficiency syndrome (AIDS) and the initial scientific ignorance on the subject, which called the condition a "gay disease." Despite this setback, in 1985 the Federal Medical Council (CFM) removed 'homosexuality' from the list of diseases. In the US, for example, being gay has not been considered a disease by the American Psychological Association (APA) since 1970 (MOTT, 2006; FACCHINI and FRANÇA, 2009).

In the 1990s the number of gay organizations increased, with the establishment of several of them acting on a variety of issues. This expansion and activity diversification led to the approximation of LGBT movements to political parties, such as the Workers' Party (PT) and the Unified Workers' Socialist Party (PSTU), as well as with other social actors. Although the authors already use the initialism LGBT for this period in history, they recognize that it was only from the 2000s that LGBT gained representativeness in public policies and governmental agenda (FACCHINI and FRANÇA, 2009).

With the diversification of the agenda and the inclusion of other social actors in the discussion of the issues (such as the press, government agencies in various disciplinary fields - health and law, for example) LGBT organizations began to compete with each other, disputing spaces, resources, legitimacy and, consequently, exactly who they are fighting for. According to the authors, these organizations go through a process of "entrepreneurship" of the LGBT movement (FACCHINI and FRANÇA, 2009).

It is in the process of establishing who is being represented by the initialism, that the idea of LGBT collective identities was consolidated in Brazil. During the 1990s the initialism began to diversify, including political subjects of gay rights such as lésbicas [lesbians] (from 1993), travestis [transvestites] (as of 1999), and transgêneros [transgender] (from 2005) (FACCHINI and FRANÇA, 2009). Facchini (2005) explained the history of the initialism analyzing the term 'lésbica,' [lesbian] and discussing the lack of visibility of the category (CARRIERI, SOUZA and AGUIAR, 2014). In field research conducted in the Corsa group, Facchini (2005) noticed that the female participants resisted the adoption of the term 'lésbica,' preferring to call themselves "homossexuais" [homosexuals] or "entendidas" [experts], justifying that the terms were more socially acceptable. The researcher identified studies produced between 1985 and 1995, pointing out resistance to the term 'lésbica.' One action to fight this resistance toward the adoption of the category lesbian was the change in the initialism for gays, lesbians, bisexuals, transvestites, transsexuals (GLBT) for LGBT at the GLBT National Conference in 2008, bringing the lesbians to the beginning of the initialism (FACCHINI, 2005; FACCHINI and FRANÇA, 2009).

Facchini and França (2009, p. 63) explain that bisexuals were not effectively recognized "as members of this political subject" (LGBT). Within the movements, there is a negative image of bisexuality. Hayfield, Clark and Halliwell (2014) illustrate this resistance in the British context, showing that bisexual women feel misunderstood by both LGBT and heterosexual groups. 
Bisexuality is understood in the most diverse social circles "as a temporary phase on the path to a fully realized lesbian or heterosexual identity and bisexuals as immature, confused, greedy, untrustworthy, highly sexual and incapable of monogamy" (HAYFIELD, CLARK and HALLIWELL, 2014, p. 352).

Finally, the letter " $\mathrm{T}$ " that reflects the two groups "transexual" [transsexual] and "transvesti" [transvestite] was an attempt to reconcile identities that in certain contexts can be considered opposed to each other. In the late 1990s the term "transgênero" [transgender] was used, but during the LGBT Meetings of the mid-2000s, it was agreed that this word was not representative of the Brazilian social environment (FACCHINI and FRANÇA, 2009). Recognizing the importance of the social achievements of LGBT movements in the last decades, Facchini (2012) suggests that the concept of social markers of difference should be considered as a way to research genres and sexualities. These markers incorporate not only gender and gender identities, but generational intersects, class, color, or race issues, corroborated to arguments put forward by Scott (1986) and Irigaray and Freitas (2011).

The understanding of the social markers of difference would thus allow the perception of hierarchies that produce "vulnerabilities and possibilities of management of social conventions" (FACCHINI, 2012, p. 145). In this sense, the author argues that there is an incompleteness in understanding the mechanisms of oppression that operate toward LGBT people considering only the stable, crystallized, and universalizing image of these identities.

\section{WHAT DOES THE INITIALISM LGBT REPRESENT? WHAT DOES IT EXCLUDE? THOUGHTS FROM CONTINGENT IDENTITIES}

[...] regarding the issue of the problematization of sexuality in school, it is crucial that it occurs within the scope of the new perspectives of post-structuralist and post-gender identity studies, so that we can refuse the places defined for dichotomies between masculine and feminine, as well as to reconstruct the meanings of bodies, desires and pleasures (CAESAR, DUARTE, and SIERRA, 2013, p. 199).

Judith Butler challenges the issue of the subject's universality. She explains, however, that questioning does not represent the negation of the subject, but the inquiry of the process of construction of this subject and the political implications of considering the subject something precedent to the theory. The author questions: "Is the effort to colonize and domesticate these theories under the sign of the same, to group them synthetically and masterfully under a single rubric, a simple refusal to grant the specificity of these positions, an excuse not to read, and not to read closely?" (BUTLER 1998, p. 14). In this context, it is attractive to problematize the alleged existence of a broad universality in the LGBT concept.

When challenging the modernist project, the author aims to challenge how an exclusionary mechanism operates, erasing what does not fit in a model, in this notion of universal. Butler (1998, p. 16) states that "the task is to interrogate what the theoretical move that establishes foundations authorizes, and what precisely it excludes or forecloses." For the author, when one considers any social phenomenon as universal, they produce new exclusions.

However, in defending the idea that something 'universal' cannot be universal, Butler stresses that she is not advocating the destruction of categories that try to understand the world, but to defend contingency, openness, and inclusion to what needs to be included in the future. The author says: "In this sense, I am not doing away with the category, but trying to relieve the category of its foundationalist weight in order to render it as a site of the permanent political contest." (BUTLER, 1998, p. 17)

When one composes and makes assumptions about a subject, they refuse "to acknowledge that agency us always and only a political prerogative." (BUTLER, 1998, p. 22). Therefore, the author argues that one must ask what conditions make action possible and in what ways one can rework "that very matrix of power by which we are constituted." To illustrate the concept of exclusion occurring within a category, Butler uses the example of the feminist movement. How can a concept aimed at solidarity produce exclusion? That is precisely what happens in a movement of universalization put forward by the categories when trying to produce a "we," which ends up producing a "we, casting some aside."

As much as the feminist movement has attempted historically to produce a feminist "we," as Butler (1998, p. 24) explains in her example, it is recurrent the return of excluded groups that end up disturbing the alleged order that "we" tried to establish. Butler realizes that the feminist movement intends to speak for all women and the author does not question 
this movement because "surely, that is how representation politics operates." That is, for women to have achieved legal gains and achievements, the existence of groups that make claims on behalf of all women as a universal group was indeed necessary.

However, Butler points out that it is necessary to think, at the same time, about the consequences of the use of the 'feminine' as a universalizing category. Because it imposes limits on who speaks, feminism is fragmented based on the descriptive elements used to define what can be included in the movement: does the movement allow the possibility of maternity and playing the role of mother according to a biological or social logic that frames the notion of woman? Also, what about women who do not want to be mothers? The ones who cannot be mothers? Suddenly white women are included, but how about black women? Butler (1998) explains the consequences of the attempt to universalize the 'feminine' and that any attempt at universalization will consequently imply exclusion, which is also corroborated by Souza (2017) in elucidating the refusal of the queer analysis to the essentialist and universalist perspectives of identities.

When discussing the example of feminism, Butler (1998, p. 25) explains that she is not advocating the "death of the category," but bringing to light that woman is a concept that cannot be universalized through a "descriptive identity." The author argues, therefore, that the categories are prone to become "a site of permanent openness and resignifiability." It should be noted that Butler does not advocate a possible reconciliation of these sites of openness, because disagreements constitute the "ungrounded ground of feminist theory." Therefore, deconstructing the universal ideal of the subject in the category, represents the possibility of freedom from restrictive ontologies, of a single referent, allowing for the expansion of possibility and the "capacity to act."

Butler's example of the risks of producing exclusion through the universalizing operation of a category can be extended to LGBT groups. The exclusionary operation with the attempt to universalize the LGBT category can be understood in work by César, Duarte, and Sierra (2013), which analyzes the category LGBT from the perspective of state public policies in the field of education.

Based on Foucault's thoughts, which are the same ontological foundation as Judith Butler's contribution, the authors study the demands of the constituted LGBT movement throughout history and the conquest of civil rights, such as same-sex civil union. The return to the first movements of the Brazilian LGBT social movement, led by gay people in the late 1980s, shows the need to fight AIDS, pressing the state to intervene in the context of public health policies. César, Duarte and Sierra (2013, p. 194) explain that this moment was "the embryo of what will later become a markedly pacified relationship between the Brazilian state and those social movements."

The historical continuity of the relations between the gay movement and the state pointed out by the authors dialogues with Butler's ideas of contingent identity. According to Butler, the creation of a common identity for the group was strategic so that it was possible to obtain from the state interventions that guarantee rights that were previously denied, such as the right to civil union (CÉSAR, DUARTE and SIERRA, 2013).

The consolidation of the gay movement was accompanied by the distribution of demands from the entry of other identity groups with specific needs, consolidating the LGBT movement from the 1990s onwards with lesbian, gay, bisexual and transvestite. César, Duarte, and Sierra (2013) emphasize the importance of these movements as a source for the state to create public policies. However, they warn of the possible consequences of this collaborative relationship.

When establishing an "alliance" with the state to obtain the rights demanded by certain LGBT groups, there is also the possibility of creating and maintaining a pacified relationship with the government, subverting the proposal of changing the social order that was present at the very beginning of the gay movement in the mid-1980s. César, Duarte and Sierra (2013, p. 195) explain that the idea of identifying a subject of rights, however recognizing the legitimacy of these rights, "is associated with the production of new control and regulation of bodies, lifestyles, and sexual and social practices." In this perspective, the authors' reflection allows observing the creation of a "pacified LGBT," limited to be a tolerable margin of the heteronormative culture that remains central.

Thus, the creation of a common representative identity of gays and lesbians for the implementation of public policies creates, from the authors' perspective, the "normal" gay and lesbian. Transvestites and transsexuals are included in medical protocols under pathological optics, and their sexuality is subject to being adequate through interventions for sexual reassignment. Thus, 
an ideal 'stable identity type' of LGBT is created, on the fringes of (but tolerated by) the heteronormative center, because it does not threaten its stability (CÉSAR, DUARTE and SIERRA, 2013).

The authors problematize this so-called universality of what they call "subjects of sexual diversity," because the creation of these LGBT subjects in public policies normalizes these categories but remains averse to those that do not fit into any of these categorical descriptions embedded in each letter (CÉSAR, DUARTE and SIERRA, 2013, p. 197). As an example of this normalization in education, the authors emphasize the contents of sexual and gender identities: "in educational texts, these identities are exemplified by characteristics or stereotypes that should be questioned."

Historically, there was a previous move toward gays and lesbians so that they are considered, in words by Renn (2010, p. 134) "'normal', just like everyone else [...] and deserved the same chance of succeed" referring to the emergence of gay and lesbian movements in the context of American universities in the 1980s. However, there is also a movement around the "normalization" of transvestite and transsexual identities. As previously mentioned, and according to the authors' report on the attempts to normalize the " $T$ " identities under the intervention of the state, it is possible to argue for the institutionalization of the surgical interventions for the adaptation of the trans bodies to the feminine or masculine esthetics. Challenging this context as Butler did when discussing women and the idea of motherhood, one may question: to what extent does every transsexual need to readjust their genitalia? Does every trans worker need to have a body similar to that of the cisgender woman? Why? (CÉSAR, DUARTE and SIERRA, 2013).

Again, it is worth noting that Butler (1998) and César, Duarte and Sierra (2013, p. 197) do not deny the importance of the social and political spaces historically won by LGBT social movements, but to challenge the "predominance or exclusivity of the idea of subject of rights, because of its normalizing conformation." Therefore, to reflect on the exclusions occurred when a stable and homogeneous identity is considered, and also on the refusal of what is outside the curve of the policies based on fixed representations of the LGBT identity.

\section{HOW ARE LGBT CATEGORIES PORTRAYED IN BRAZILIAN ADMINISTRATION JOURNALS?}

Despite the alleged universality expressed by the initialism LGBT, the corpus of articles published in administration journals shows the differences within the groups. The first difference can be understood in the representativeness perceived through the number of articles in each category of identity, as shown in Box 1.

Box 1

Panorama of the research works on LGBT in Brazilian Administration journals between 2006 and 2017

\begin{tabular}{|c|c|c|c|}
\hline Authors & Journal & Qualis**** & Central theme \\
\hline \multicolumn{4}{|c|}{$L G B T$} \\
\hline $\begin{array}{c}\text { Azevedo, Martins, } \\
\text { Pizzinatto et al. (2012) }\end{array}$ & Revista de Administração da UFSM & B1 & $\begin{array}{c}\text { Tourism at the São Paulo } \\
\text { LGBT Pride Parade }\end{array}$ \\
\hline $\begin{array}{l}\text { Natt, Saraiva and Carrieri } \\
\text { (2015) }\end{array}$ & $\begin{array}{c}\text { Revista Eletrônica de Ciência } \\
\text { Administrativa }\end{array}$ & B1 & $\begin{array}{l}\text { Bathrooms exclusively for } \\
\text { LGBT persons }\end{array}$ \\
\hline \multicolumn{4}{|c|}{ Lesbians } \\
\hline $\begin{array}{l}\text { Siqueira and Zauli-Fellows } \\
\qquad(2006)^{*}\end{array}$ & Gestão.Org & B2 & Discrimination in work relations \\
\hline Irigaray and Freitas (2011) & Organizações \& Sociedade & $\mathrm{A} 2$ & $\begin{array}{l}\text { Lesbians' self-perception } \\
\text { in the work environment }\end{array}$ \\
\hline $\begin{array}{l}\text { Souza Júnior, Cerquinho, } \\
\text { Nogueira et al. (2013)* }\end{array}$ & Pensamento \& Realidade & B3 & Harrassment \\
\hline $\begin{array}{l}\text { Carrieri, Souza and Aguiar } \\
\qquad(2014)^{* *}\end{array}$ & Revista de Administração Contemporânea & A2 & $\begin{array}{l}\text { Violence in society and } \\
\text { the work place }\end{array}$ \\
\hline
\end{tabular}


Continue

\begin{tabular}{|c|c|c|c|}
\hline Authors & Journal & Qualis**** & Central theme \\
\hline \multicolumn{4}{|c|}{ Gays } \\
\hline $\begin{array}{l}\text { Pereira, Ayrosa and Ojima } \\
\text { (2006) }\end{array}$ & Cadernos EBAPE.BR & $\mathrm{A} 2$ & Identity building via consumption \\
\hline $\begin{array}{l}\text { Siqueira and Zauli-Fellows } \\
\text { (2006) }\end{array}$ & Gestão.Org & B2 & Discrimination in work relations \\
\hline $\begin{array}{c}\text { Araújo, Alexandre, Pereira } \\
\text { et al. (2010) }\end{array}$ & Revista Ciências Administrativas & B2 & $\begin{array}{c}\text { Comparison between the } \\
\text { consumption of gays and } \\
\text { heterosexuals in malls }\end{array}$ \\
\hline Garcia and Souza (2010) & Revista de Administração Pública & A2 & $\begin{array}{l}\text { Discrimination in the banking } \\
\text { sector }\end{array}$ \\
\hline $\begin{array}{l}\text { Irigaray, Saraiva and } \\
\text { Carrieri (2010) }\end{array}$ & Revista de Administração Contemporânea & A2 & Humor as discrimination \\
\hline $\begin{array}{l}\text { Curzio, Altaf and Troccoli } \\
\text { (2011) }\end{array}$ & REUNA & B3 & Consumption of entertainment \\
\hline Tirelli (2011) & $\begin{array}{l}\text { Pensamento Contemporâneo em } \\
\text { Administração }\end{array}$ & B2 & $\begin{array}{l}\text { Consumption of night life for gay } \\
\text { couples }\end{array}$ \\
\hline Altaf e Troccoli (2012) & Revista Ciências Administrativas & B2 & Consumption of luxury clothing \\
\hline $\begin{array}{c}\text { Altaf, Troccoli, Paschoalino } \\
\text { et al. (2012) }\end{array}$ & $\begin{array}{c}\text { Revista Eletrônica de Ciência } \\
\text { Administrativa }\end{array}$ & B1 & Consumption of luxury clothing \\
\hline $\begin{array}{l}\text { Pereira and Ayrosa } \\
\qquad(2012 a)\end{array}$ & Brazilian Administration Review & $\mathrm{A} 2$ & $\begin{array}{c}\text { Consumption as a symbolic barrier } \\
\text { between the worlds of gays and } \\
\text { heterosexuals }\end{array}$ \\
\hline $\begin{array}{l}\text { Pereira and Ayrosa } \\
(2012 b)\end{array}$ & Organizações \& Sociedade & $\mathrm{A} 2$ & Body and consumption \\
\hline $\begin{array}{l}\text { Altaf, Troccoli and Moreira } \\
\text { (2013) }\end{array}$ & Revista de Administração UFSM & B1 & Consumption of luxury clothing \\
\hline $\begin{array}{l}\text { Carrieri, Aguiar and Diniz } \\
\text { (2013) }\end{array}$ & Cadernos EBAPE.BR & $\mathrm{A} 2$ & $\begin{array}{c}\text { Theoretical discussion on } \\
\text { harrassment }\end{array}$ \\
\hline $\begin{array}{c}\text { Diniz, Carrieri, Gandra } \\
\text { et al. (2013) }\end{array}$ & Economia e Gestão & B2 & $\begin{array}{c}\text { Policies on diversity and work } \\
\text { relations }\end{array}$ \\
\hline $\begin{array}{l}\text { Oliveira, Troccoli, and Altaf } \\
\text { (2013) }\end{array}$ & Revista Administração em Diálogo & B3 & Tattoos as an expression of identity \\
\hline $\begin{array}{l}\text { Silva, Furtado, Lima et al. } \\
\text { (2013) }\end{array}$ & Revista ADM.MADE & B2 & Building identity at work \\
\hline $\begin{array}{l}\text { Souza Júnior, Cerquinho, } \\
\text { Nogueira et al. (2013)* }\end{array}$ & Pensamento \& Realidade & B3 & Harrassment \\
\hline Souza and Pereira (2013) & Revista de Administração Mackenzie & B1 & $\begin{array}{l}\text { Discrimination of homosexuals by } \\
\text { homosexuals }\end{array}$ \\
\hline Silva and Leite (2014) & Revista Ciências Administrativas & B2 & Experiences of hotel consumption \\
\hline $\begin{array}{c}\text { Caproni Neto, Saraiva and } \\
\text { Bicalho }(2014)^{*}\end{array}$ & $\begin{array}{l}\text { Revista Pensamento Contemporâneo em } \\
\text { Administração }\end{array}$ & B2 & $\begin{array}{c}\text { Consequences of 'coming out' at } \\
\text { work }\end{array}$ \\
\hline $\begin{array}{l}\text { Eccel, Saraiva and Carrieri } \\
\text { (2015) }\end{array}$ & $\begin{array}{l}\text { Pensamento Contemporâneo em } \\
\text { Administração }\end{array}$ & B2 & Social represented masculinity \\
\hline $\begin{array}{l}\text { Souza, Martins and Souza } \\
\text { (2015) }\end{array}$ & Gestão \& Conexões & B4 & $\begin{array}{c}\text { Social representation of gay } \\
\text { executive secretaries }\end{array}$ \\
\hline Colares and Saraiva (2016) & Revista Alcance & B2 & Personal and professional identity \\
\hline $\begin{array}{l}\text { Moura, Nascimento and } \\
\text { Barros (2017) }\end{array}$ & $\begin{array}{l}\text { Farol: Revista de Estudos Organizacionais } \\
\text { e Sociedade }\end{array}$ & B4 & Effeminate Gays in organizations \\
\hline
\end{tabular}




\begin{tabular}{|c|c|c|c|}
\hline Authors & Journal & Qualis**** & Central theme \\
\hline \multicolumn{4}{|c|}{ Gays } \\
\hline Rabelo and Nunes (2017) & Economia \& Gestão & B2 & $\begin{array}{c}\text { Consequences of 'coming out' at } \\
\text { work }\end{array}$ \\
\hline $\begin{array}{l}\text { Santos, Silva and } \\
\text { Cassandre (2017) }\end{array}$ & Revista de Carreiras e Pessoas & B4 & $\begin{array}{l}\text { Standard in contracting gay people } \\
\text { in malls }\end{array}$ \\
\hline \multicolumn{4}{|c|}{ Bisexuals } \\
\hline \multicolumn{4}{|c|}{ No publications were found*** } \\
\hline \multicolumn{4}{|c|}{ Transvestite and transsexual } \\
\hline Muller and Knauth (2008) & Cadernos EBAPE.BR & $\mathrm{A} 2$ & $\begin{array}{l}\text { Marginalizing transvestites in } \\
\text { public healthcare services }\end{array}$ \\
\hline $\begin{array}{l}\text { Carrieri, Souza and Aguiar } \\
\qquad(2014)^{* *}\end{array}$ & Revista de Administração Contemporânea & $\mathrm{A} 2$ & $\begin{array}{l}\text { Violence in the context of society } \\
\text { and work }\end{array}$ \\
\hline $\begin{array}{l}\text { Caproni Neto and Saraiva } \\
\text { (2014) }\end{array}$ & Teoria e Prática em Administração & B2 & $\begin{array}{l}\text { Stigma around transvestites in the } \\
\text { professional environment }\end{array}$ \\
\hline Baggio (2017) & Revista de Gestão - REGE & B1 & $\begin{array}{l}\text { Experiences of male and female } \\
\text { transsexuals in organizations }\end{array}$ \\
\hline
\end{tabular}

Source: Elaborated by the author.

Notes:

* The works by Siqueira and Zauli-Fellows (2006), Souza Júnior, Cerquinho, Nogueira et al. (2013) and Caproni Neto, Saraiva and Bicalho (2014) approach experiences of gays and lesbians.

** The work by Carrieri, Souza and Aguiar (2014) is a study on lesbians, transvestites and transsexuals.

*** The work by Caproni Neto (2017), presented at the 20th Seminar in Administration of FEA-USP, is considered a pioneer study.

**** Qualis: Brazilian system of classification of scientific publications. The classification is ranked from A1 for the highest, then A2; B1; B2; B3; B4; B5; and finally C (for publications not listed).

Between 2006 and 2017, the study identified 34 articles that addressed the groups in the initialism LGBT. Among the 34 articles, two addressed LGBT issues, considered as a general group, five articles address lesbian issues, 26 gay issues, and four articles deal with transvestite and transsexual issues. Some studies have addressed more than one identity category, which was the case of the work by Carrieri and Souza Aguiar (2014), discussing issues in the categories lesbians and transvestite and transsexual, and Siqueira and Zauli-Fellows (2006) and Souza Júnior, Cerquinho, Nogueira et al. (2013), who analyzed gays and lesbians. For each article, there was a process of reading and interpretation that allowed to delimit the central theme presented by the authors of the research, data compiled in Box 1.

The themes observed in these articles covered topics such as violence, discrimination, harassment, stigmatization, consumption habits, masculinities, gender identity and work, work experiences, and policies regarding diversity. Among these themes, two main narratives are recurrent in the studies. The first one shows the predominance of negative societal reactions in the research findings, i.e., the studies expressed the fact that the coexistence of LGBT people in society and organizations is still far from being respected. For some groups, such as gay men and lesbians, this collective living is somehow tolerated (IRIGARAY, 2012).

In this narrative, one of the studies stands out in which the authors use LGBT in general as an identity category (NATT, SARAIVA and CARRIERI, 2015). This article is an example to understand the importance of the constitution of the collective subject of right. The authors discuss the possibility of adopting exclusive bathrooms designated to the LGBT people and demonstrate that the alleged inclusive aspect of such a practice, may represent a form of segregation and social hierarchy toward this group. The authors perspective corroborates Butler's (1998) and César, Duarte and Sierra's (2013) argument that the voice that is put forward on behalf of the groups is needed, in order to fight for and guarantee social spaces and rights. 
The second main narrative observed in the examination is related to consumption, and it refers almost exclusively to the gay public. The only exception was the other study adopting LGBT in general as an identity category (AZEVEDO, MARTINS, PIZZINATTO et al., 2012), which shows, based on secondary data, the consumption profile of LGBT tourists. However, it is worth noting that the articles using the consumption narrative presented two different analytical focuses, both originated in the field of marketing. The first focus, from a business point of view (market), considers 'gay' as a homogeneous group, identified as a demographic category with high education and high consumption potential (ARAÚJO, ALEXANDRE, PEREIRA et al., 2010; SILVA and LEITE, 2014; CURZIO, ALTAF and TROCCOLI, 2011; TIRELLI, 2011; ALTAF and TROCCOLI, 2012; ALTAF, TROCCOLI, PASCHOALINO et al., 2012; AZEVEDO, MARTINS, PIZZINATTO et al., 2012; ALTAF, TROCCOLI and MOREIRA, 2013).

The second analytical focus is related to culture and the social construction of gay identities through consumption, considering the specific characteristics of identity constitution for the groups studied (PEREIRA, AYROSA and OJIMA, 2006; PEREIRA and AYROSA, 2012a, 2012b). The focus highlights that the consumption, in the cultural point of view, presents a historical view regarding the social construction of identity in the "gay" category, recognizing it as an unstable category and that connects to other categories of social life such as work, age, social class. The articles also highlight the cultural differences built by gay men related to heterosexuals, highlighting the aesthetic and corporal issues that are valued in the consumption experiences of gay men. There is, however, an exclusion in the theme consumption and culture, because all research examined in the field refers to male experiences (PEREIRA, AYROSA and OJIMA, 2006; PEREIRA and AYROSA, 2012a, 2012b).

The negative reactions of society, such as discrimination, violence, or stigma, could be observed in the case of all groups represented in the initialism LGBT. As for lesbians, violence is expressed through the imposition of the binary heterosexual matrix of gender, considering that they experience violence imposed by the heterosexual reproductive pattern. Many of them have heterosexual marriages and children before coming out as lesbians. Also, they are forced to assume a social behavior considered feminine - long hair, "female-style" walking (CARRIERI, SOUZA and AGUIAR, 2014). Also, Irigaray and Freitas (2011) discuss, based on empirical study, that lesbians do not share the same spaces of identity expression of gays since they also have attitudes that reproduce the exclusion of women in the social space.

As for gays, the manifestations of discrimination and social hostility in administration research incorporate the discussion about invisibility, because coming out in the context of work can be a risk, which is an issue also for lesbian workers (CAPRONI NETO, SARAIVA and BICALHO, 2014). Only those who decide not to come out as openly gay and remain invisible, survive at work. Whoever "comes out" is mistreated, becomes a target of jokes and can be fired (SOUZA JÚNIOR, CERQUINHO, NOGUEIRA et al., 2013). In fact, humor as an instrument of violence and discrimination is a recurring finding in the research works, in which jokes may be made from both heterosexual and gay people (GARCIA and SOUZA, 2010; IRIGARAY, SARAIVA and CARRIERI, 2010; DINIZ, CARRIERI, GANDRA, et al., 2013). Another study, a case of teaching, found that there are companies that accept a gay worker, as long as 'he does not appear to be gay,' i.e., in the way he dresses, behave and live with a group that characterizes him as such (COLARES and SARAIVA, 2016).

Regarding the way people look, one of the pioneering articles on the field of gay identity (SIQUEIRA and ZULI-FELLOWS, 2006) addresses precisely the issue of "coming out," discussing the need for companies to be prepared to live with gay and lesbian people in their staff. Another recurring point in the researched articles is the hierarchy of identities, in which those considered "males" discriminate and command the gay identities considered "effeminate" (ECCEL, SARAIVA and CARRIERI, 2015). Gays considered as non-effeminate discriminate and reproduce discrimination against effeminate gays (MOURA, NASCIMENTO and BARROS, 2017). Being effeminate, in this context, makes of the gay person someone considered "inferior" (SOUZA and PEREIRA, 2013; SANTOS, SILVA and CASSANDRE, 2017).

Although society hostility has been recurrent among gay and lesbian research, the transvestite and transsexual populations are in an even more subaltern position in administration research. Formal work is also found to be practically non-existent because, as Caproni Neto and Saraiva (2014) argue, the presence of transvestites is not accepted or tolerated in the formal workspaces, leaving them with few professional alternatives to prostitution. A book chapter was published in the area, presenting the social scenario of impossibilities for transvestites to enter the labor market and build corporate careers, even if they are professionally qualified (IRIGARAY, 2012).

The research by Carrieri, Souza and Aguiar (2014) corroborated the scenario that, because they cannot hide what they are in social life (with a body considered as 'abnormal'), transvestites are more likely to suffer violence, including physical violence, 
which contributes to confirm their difficulty in accessing the formal labor market (IRIGARAY, 2012; CARRIERI, SOUZA and AGUIAR, 2014). However, it is important to reinforce the argument that, before discussing the business scenario, the very lack of access to basic social rights such as education, security, and health makes the situation of transvestites and transsexuals in Brazil even more critical. The social experiences, in this case, are constituted mainly by the feeling of abjection (MULLER and KNAUTH, 2008; BERUTTI, 2010; IRIGARAY, 2012; CARRIERI, SOUZA and AGUIAR, 2014).

Among female transsexuals, one of the forms of violence occurs through the reproduction of gender binarism, when they are forced to undergo medical and surgical procedures to fit into what is aesthetically and socially "fit" as a woman's body (CARRIERI, SOUZA and AGUIAR, 2014). Regarding the world of work, Baggio (2017) shows that the experience of trans people depends heavily on the degree to which transgender people are taken as cisgender, what the author calls "passability" (BAGGIO, 2017, p. 365). Therefore, the more transsexual men and women look like the people suited to their gender, the less likely they are to be victims of transphobic violence at work.

As for bisexual identities, although they were absent from Brazilian administration journals in the period researched (20062017), the issue was under debate in events of the field (CAPRONI NETO, 2017). A clue about the possible causes for the 'invisibility' of this social group in research in Administration is the perception of this characteristic as a transitory stage, or even "confusion and instability" between being hetero or homosexual. Also, organizations with diversity policies tend to address this identity group as gays and lesbians, with bisexuality as a neglected dimension of sexuality. Besides, work colleagues, including gays and lesbians, can create environments that may exclude those who declare themselves to be bisexual, which demarcates the existence of biphobia as an organizational phenomenon distinct from homophobia and transphobia (KÖLLEN, 2013; CAPRONI NETO, 2017).

The LGBT representation gap in administration, especially regarding lesbians, bisexuals, and transvestites and transsexuals, is, therefore, a central element to understand the scenario observed in the bibliographic examination conducted in this study, as well as to plan future research opportunities. Most of the research carried out in the area of administration is in the context of business. However, for almost two decades there has been a movement proposing to expand the analysis of organizational phenomena, considering that management should be a phenomenon understood beyond corporate boundaries because in the most diverse spheres of society there are collective and social management processes to be studied (FISCHER, 2001). It is possible to say that the expansion of the boundaries for the analysis of the organizational phenomenon was confirmed, based on the recognition that the most recent organizational research has included in its scope people outside the business environment, "but who work in an organizational sphere of a more social dimension" (TEIXEIRA, SARAIVA and CARRIERI, 2015, p. 176).

In the context of the people who are part of LGBT groups, therefore, other research scenarios can be glimpsed in the administration. Although many of these subjects are not in formal jobs in companies, the struggle for rights and spaces in society mobilizes some actors in various organized social movements. An example of this type of organization is that, in large cities, there are institutions that serve as a space for the reception of LGBT people who are victims of violence and expelled from their homes. The international literature on organizational diversity already recognizes the need for further research on alternative forms of organization, so that it is feasible, in practice, to pursue social justice (PULLEN, VACCHANI, GAGNON et al., 2017).

\section{DISCUSSION AND FINAL CONSIDERATIONS: RESEARCH POSSIBILITIES IN ADMINISTRATION}

This examination of the articles on LGBT published in Brazilian administration journals shows that, although there are similarities - in the sense that all these identity groups are considered deviants and subject to discrimination and violent social manifestations - there are also clear differences between them. Because of these differences, discussed in work by Judith Butlers, it is possible for administration research to think about whether it is feasible to adopt the category LGBT as a universal and unified concept in administration. However, this difference needs to be constructed permanently, always being open to reinterpretations, as suggested by Butler (1998). 
The representativeness of LGBT in administration research indicates that the field is open to addressing issues of sexuality and gender, considering the number of published works (over 30). However, it is important to note that the debate remains predominantly restricted to organizational experiences of male individuals, reinforcing the historical background of inequality between men and women.

Thus, the publications of the administration journals are still at a stage of construction of the idea of the political subject of diversity, because it has not yet been possible to contemplate the broad spectrum of LGBT identities, even when they are taken by a collective category of subjects. It will be important to embrace other identities not contemplated in the categorical descriptions of what is gay, lesbian, bisexual, transvestite and transexual, given that the initialism LGBT is surrounded by historical dynamics of groups. These groups have claimed in recent years the inclusion of other letters representative of others political subjects such as LGBTQI (lesbian, gay, bisexual, transexual, transgender, queer, and intersexual) - including 'queer/ questioning' and 'intersexual' people.

Although this is a recent field of research, emerging in the international debate only between the 1980s and 1990s, and considering that SPELL is a database that currently contains more than 45,000 documents, it is interesting to problematize the fact that only 34 articles on LGBT in Brazilian administration journals were identified (and that the most significant part of the articles are focused on gay). This scenario opens space to question: to what extent are research works in administration recognizing the existence of alternative sexual preferences and gender identities?

Reflecting on the examination of the literature on LGBT in administration in the light of the theorization discussed in the article, perhaps the Brazilian field of administration is a little behind, experiencing a process that was lived in the early 1990 s by the movements for LGBT rights. This assumption is based mainly on the low number of articles on lesbian, bisexual, transvestite, and transsexual categories, as well as the fact that the themes that dominate the published research are related to negative manifestations (evidencing that the work environment in companies is not favorable even to the stereotypically "well-behaved" lesbians and gays, to those considered "normal" and "tolerable"). Also, regarding the theme of consumption, the research public is limited to a particular part of the gay society: well-educated white men.

This study conducts a critical analysis, considering the elements that identify this type of analysis pointed out by Fournier and Grey (2000). Firstly, it was found that, regarding the LGBT identities, the business environment is hostile, even to the identity that was initially supposed to be more included, i.e., cisgender gay men or lesbians. The examined articles indicate that hostility in the workplace is reproduced by gays and lesbians themselves. As for transvestites and transsexuals in the world of work, considering the context where they have difficulties to access public health and education services, they face enormous difficulties to access regular employment.

As for denaturalization, once again it is necessary to reflect: how to denaturalize the alleged universalization of LGBT subjects if the categorical construction "universal" of the initialism is marginal in the debates in administration journals? Finally, the reflections support that it is still necessary to think both of the particularities, i.e., each of the identity groups represented in the initialism, and of what is considered an LGBT identity. It is crucial to understand that there are multiple identities beyond the imposed limits of what may be lesbian, gay, bisexual, and transvestite/transsexual and that there is a need to produce more knowledge about the subjects characterized in the LGBT identity groups.

The current scenario in administration is conducive to more researchers entering the debate, because the differences between LGBT identity groups can still be studied in relation to other types of differences, such as geographical (because articles found presented research conducted in several states and cities of Brazil), professional (because the experience of being part of an LGBT group may vary according to the profession of the individuals and some studies focused on specific occupations such as bank employees and executive secretaries), and socioeconomic (because issues such as social class and race have been claimed in research that understands diversity in organizations, providing many research scenarios) (ZANONI, JANSSENS, BENSCHOP et al., 2010; IRIGARAY and FREITAS, 2011).

As for the limitations of this study, it considered only the scientific production published in Brazilian academic journals not covering the production presented and debated at events in the field, which may bring some developments not captured here. It seems plausible, for example, to research the complete process of scientific dissemination. In practice, an alternative may be to search for works presented at events in the field, establishing a dialogue with authors about the subsequent dissemination of their research in the journals. In this way, it would be possible to investigate whether there are barriers to journals in the area for publication of research on the various experiences of LGBT audiences. 
In short, although this article has presented a debate guiding researchers to reflect on the homogenous and universalizing appropriations of the initialism LGBT, such appropriation is more present and consolidated in the English-speaking literature, although it is necessary to pay attention to the differences within the initialism (KÖLLEN, 2013; NG and RUMENS, 2017). The research gaps in Brazil regarding the social and organizational experiences of people in LGBT groups are evident, due to the lack of works, both when LGBT is taken as a collective of subjects of rights, and as if they are considered the social groups contained in the initialism, with their nuances and peculiarities. However, it is important to emphasize that the subrepresentativeness of LGBT groups is not only relevant to the context of research in administration. It rather reflects Brazilian society itself, because, as Freitas (2015) analyzed, when studying the organizational diversity policies in the country, it is still necessary that public policies are created to enable better treatment of LGBT groups by the agents of the labor market.

It is, therefore, necessary to return to the metaphors to characterize the identities in the title of the article. Thinking about the emergence, gays allow this analogy, given that they are the most representative category in the study. As for submersion, we have lesbians, whose underrepresentation in research is twofold, because, in addition to the social adversities related to sexual orientation, they face the difficulties of being women. The use of 'silence' is applied to transvestite and transsexual identities because although there is some research in the Brazilian administration, this group is the most marginalized in management and in the workplace, which is the most general context of research in the field. 


\section{REFERENCES}

ALCADIPANI, R. Réplica: a singularização do plural. Revista de Administração Contemporânea, v. 9, n. 1, p. 211-220, 2005.

ALTAF, J. G. et al. Luxury clothing: a mirror of gay consumers sexual option? Revista Eletrônica de Ciência Administrativa, v. 11, n. 1, p. 162-177, 2012.

ALTAF, J. G.; TROCCOLI, I. G. Luxo sou eu: as marcas famosas e o consumidor homossexual. Revista Ciências Administrativas, v. 18, n. 2, p. 656-688, 2012.

ALTAF, J. G.; TROCCOLI, I. R.; MOREIRA, M. B. Você é o que você veste? A associação da autoidentidade do gay masculino ao vestuário de luxo. Revista de Administração da UFSM, v. 6, n. 4, p. 760-782, 2013.

ARAÚJO, R. et al. Comportamento dos consumidores heterossexuais e homossexuais masculinos: um estudo comparativo em Shopping Center. Revista Ciências Administrativas, v. 16, n. 1, 2010.

AZEVEDO, M. S. et al. Segmentação no setor turístico: o turista LGBT de São Paulo. Revista de Administração da UFSM, v. 5, n. 3, p. 493-506, 2012.

BAGGIO, M. C. About the relation between transgender people and the organizations: new subjects for studies on organizational diversity. Revista de Gestão - REGE, v. 24, n. 4, p. 360-370, 2017.

BERUTTI, E. B. Travestis: retratos do Brasil. In: COSTA, H. et al. (Orgs.). Retratos do Brasil homossexual: fronteiras, subjetividades e desejos. São Paulo: Imprensa Oficial do Estado, 2010. p. 843-852.

BUTLER, J. Fundamentos contingentes: o feminismo e a questão do "pós-modernismo". Cadernos Pagu, n. 11, p. 11-42, 1998.

CAPRONI NETO, H. L. A bissexualidade (des)organizada: desenhos, estigmas e subversões. In: SEMINÁRIOS EM ADMINISTRAÇÃO DA FEA-USP, 20., 2017, São Paulo. Anais... São Paulo: FEA-USP, 2017.

CAPRONI NETO, H. L.; SARAIVA, L. A. S. Estigma na trajetória profissional de uma travesti. Teoria e Prática em Administração, v. 4, n. 2, p. 234-256, 2014.

CAPRONI NETO, H. L.; SARAIVA, L. A. S.; BICALHO, R. A. Diversidade sexual nas organizações: um estudo sobre coming out. Revista Pensamento Contemporâneo em Administração, v. 8, n. 1, p. 86-103, 2014.

CARRIERI, A. P.; AGUIAR, A. R. C.; DINIZ, A. P. R. Reflexões sobre o indivíduo desejante e o sofrimento no trabalho: o assédio moral, a violência simbólica e o movimento homossexual. Cadernos EBAPE.BR, Rio de Janeiro, v. 11, n. 1, p. 165-180, 2013.

CARRIERI, A. P.; SOUZA, E. M.; AGUIAR, A. R. C. Trabalho, violência e sexualidade: estudo de lésbicas, travestis e transexuais. Revista de Administração Contemporânea, v. 18, n. 1, p. 78-95, 2014.

CÉSAR, M. R. A.; DUARTE, A.; SIERRA, J. C. Governamentalização do Estado, movimentos LGBT e escola: capturas e resistências. Educação, v. 36, n. 2, 2013.

COLARES, A. F. V.; SARAIVA, L. A. S. O processo de construção identitária em organizações: uma releitura sobre identidade. Revista Alcance, v. 23, n. 4 , p. 568-577, 2016.

CURZIO, P. H. A.; ALTAF, J. G.; TROCCOLI, I. R. Vai ao Musik? A satisfação do cliente gay com serviços e entretenimento. REUNA, v. 18, n. 1, p. 57-72, 2011.
DINIZ, A. P. R. et al. Políticas de diversidade nas organizações: as relações de trabalho comentadas por trabalhadores homossexuais. Economia \& Gestão, v. 13, n. 31, p. 93-114, 2013.

ECCEL, C. S.; SARAIVA, L. A. S.; CARRIERI, A. P. Masculinidade, autoimagem e preconceito em representações sociais de homossexuais. Pensamento Contemporâneo em Administração, v. 9, n. 1, p. 1, 2015.

FACCHINI, R. Sopa de letrinhas? Movimento homossexual e produção de identidades coletivas nos anos 90. Rio de Janeiro: Garamond, 2005.

FACCHINI, R. Entre compassos e descompassos: um olhar para o "campo" e para a "arena" do movimento LGBT brasileiro. Bagoas Estudos Gays: Gêneros e Sexualidades, v. 3, n. 4, p. 131-158, 2012.

FACCHINI, R.; FRANÇA, I. L. De cores e matizes: sujeitos, conexões e desafios no Movimento LGBT brasileiro. Sexualidad, Salud y Sociedad - Revista Latinoamericana, n. 3, p. 54-81, 2009.

FISCHER, T. M. D. Difusão do conhecimento sobre organizações e gestão no Brasil: seis propostas de ensino para o decênio 2000/2010. Revista de Administração Contemporânea, v. 5, n. esp., p. 123-139, 2001.

FOURNIER, V.; GREY, C. At the critical moment: conditions and prospects for critical management studies. Human Relations, v. 53, n. 1, p. 7-32, 2000.

FREITAS, M. E. Contexto, políticas públicas e práticas empresariais no tratamento da diversidade no Brasil. Revista Interdisciplinar de Gestão Social, v. 4, n. 3, p. 87-135, 2015.

GARCIA, A.; SOUZA, E. M. Sexualidade e trabalho: estudo sobre a discriminação de homossexuais masculinos no setor bancário. Revista de Administração Pública, Rio de Janeiro, v. 44, n. 6, p. 1353-1377, 2010.

HAYFIELD, N.; CLARKE, V.; HALLIWELL, E. Bisexual women's understandings of social marginalisation: 'the heterosexuals don't understand us but nor do the lesbians'. Feminism \& Psychology, v. 24, n. 3, p. 352-372, 2014.

IRIGARAY, H. A. R. Travestis e transexuais no mundo do trabalho. In: FREITAS, M. E.; DANTAS, M. (Org.). Diversidade sexual e trabalho. São Paulo: Cengage Learning, 2012. p. 121-148.

IRIGARAY, H. A. R.; FREITAS, M. E. Sexualidade e organizações: estudo sobre lésbicas no ambiente de trabalho. Organizações \& Sociedade, v. 18, n. 59, p. 625-641, 2011.

IRIGARAY, H. A. R.; SARAIVA, L. A.; CARRIERI, A. P. Humor e discriminação por orientação sexual no ambiente organizacional. Revista de Administração Contemporânea, v. 14, n. 5, p. 890-906, 2010.

JENNINGS, R. Lesbian voices: the Hall Carpenter oral history archive and post-war british lesbian history. Sexualities, v. 7, n. 4, p. 430445, 2004.

KÖLLEN, T. Bisexuality and diversity management: addressing the $B$ in LGBT as a relevant 'sexual orientation' in the workplace. Journal of Bisexuality, v. 13, n. 1, p. 122-137, 2013.

MOTT, L. Homo-afetividade e direitos humanos. Revista Estudos Feministas, v. 14, n. 2, p. 509-521, 2006. 
MOURA, R. G.; NASCIMENTO, R. P.; BARROS, D. F. O problema não é ser gay, é ser feminino: o gay afeminado nas organizações. Farol: Revista de Estudos Organizacionais e Sociedade, v. 4, n. 11, 14781541, 2017.

MULLER, M. I.; KNAUTH, D. R. Desigualdades no SUS: o caso do atendimento às travestis é 'babado'! Cadernos EBAPE.BR, v. 6, n. 2, p. 1-14, 2008.

NATT, E. D. M.; SARAIVA, L. A. S.; CARRIERI, A. P. Criação de banheiros LGBTS: inclusão ou prática discriminatória? Revista Eletrônica de Ciência Administrativa, v. 14, n. 1, p. 31-44, 2015.

NG, E. S.; RUMENS, N. Diversity and inclusion for LGBT workers: current issues and new horizons for research. Canadian Journal of Administrative Sciences, v. 2, n. 34, p. 109-120, 2017.

OLIVEIRA, M. J.; TROCCOLI, I. R.; ALTAF, J. G. Corpos tatuados: Uma expressão identitária do consumidor homossexual?. Revista Administração em Diálogo, v. 15, n. 3, p. 57-88, 2013.

PEREIRA, S. J. N.; AYROSA, E. A. T. Between two worlds: an ethnographic study of gay consumer culture in Rio de Janeiro. Brazilian Administration Review, v. 9, n. 2, p. 211-228, 2012a.

PEREIRA, S. J. N.; AYROSA, E. A. T. Corpos consumidos: cultura de consumo gay carioca. Organizações \& Sociedade, v. 19, p. 295-313, 2012 b.

PEREIRA, B.; AYROSA, E. A. T.; OJIMA, S. Consumo entre gays: compreendendo a construção da identidade homossexual através do consumo. Cadernos EBAPE.BR, Rio de Janeiro, v. 4, n. 2, p. 1-16, 2006.

PULLEN, A. et al. Critical diversity, philosophy and praxis. Gender, Work \& Organization, v. 24, n. 5, p. 451-456, 2017.

RABELO, A. M.; NUNES, S. C. "Sair ou ficar no armário"? Eis a questão! Estudo sobre as razões e os efeitos do coming out no ambiente de trabalho. Revista Economia \& Gestão, v. 17, n. 48, p. 82-97, 2017.

RENN, K. A. LGBT and queer research in higher education: the state and status of the field. Educational Researcher, v. 39, n. 2, p. 132-141, 2010.

SANTOS, N. S.; SILVA, L. F. M.; CASSANDRE, M. P. Quem disse Berenice, que ser gay é ser um bom vendedor de lojas de shopping? Revista de Carreiras e Pessoas, v. 7, n. 3, p. 88-112, 2017.
SCOTT, J. W. Gender: a useful category of historical analysis. The American Historical Review, v. 91, n. 5, p. 1053-1075, 1986.

SILVA, A. et al. Sentido do trabalho e diversidade: um estudo com homossexuais masculinos. Revista ADM.MADE, v. 17, n. 2, p. 85-105, 2013.

SILVA, J. P.; LEITE, Y. V. P. Reações do consumidor gay: a influência do ambiente de hotéis. Revista Ciências Administrativas, v. 16, n. 1, p. 180-198, 2014.

SIQUEIRA, M. V. S.; ZAULI-FELLOWS, A. Diversidade e identidade gay nas organizações. Gestão.Org: Revista Eletrônica de Gestão Organizacional, v. 4, n. 3, p. 69-81, 2006.

SOUZA, E. M. A Teoria queer e os estudos organizacionais: revisando conceitos sobre identidade. Revista de Administração Contemporânea, v. 21, n. 3, p. 308-326, 2017.

SOUZA, E. C. P.; MARTINS, C. B.; SOUZA, R. B. As representações sociais de secretários executivos gays: questões de gênero e diversidade no trabalho. Revista Gestão \& Conexões, v. 4, n. 1, p. 116-139, 2015.

SOUZA, E. M.; PEREIRA, S. J. N. (Re)produção do heterossexismo e da heteronormatividade nas relações de trabalho: a discriminação de homossexuais por homossexuais. Revista de Administração Mackenzie, v. 14, n. 4, p. 76-105, 2013.

SOUZA JÚNIOR, A. A. et al. Aspectos da dominação masculina no assédio moral ao profissional homossexual no Polo Industrial de Manaus. Pensamento \& Realidade, v. 28, n. 1, p. 83-103, 2013.

TEIXEIRA, J. C.; SARAIVA, L. A. S.; CARRIERI, A. P. Os lugares das empregadas domésticas. Organizações \& Sociedade, v. 22, n. 72, p. 161-178, 2015.

TIRELLI, C. Consumo de entretenimento noturno por casais gays. Pensamento Contemporâneo em Administração, v. 5, n. 2, p. 79-94, 2011.

ZANONI, P. et al. Unpacking diversity, grasping inequality: rethinking difference through critical perspectives. Organization, v. 17, n. 1, p. 9-29, 2010.

Maurício Donavan Rodrigues Paniza

ORCID: https://orcid.org/0000-0001-6544-9640

Doctoral student in administration at the Fundação Getulio Vargas, São Paulo School of Business Administration (FGV EAESP); Master's in administration from the Post-Graduation Program in Administration of the State University of Maringá (UEM); Collaborating Professor at the State University of Londrina (UEL) in the Department of Administration, São Paulo - SP, Brazil. E-mail: mauriciopaniza@gmail.com 